\title{
COVID-19 pandemic: lockdown impacts on the Indian environment, agriculture and aquaculture
}

\author{
Rajeeb K. Mohanty, Krishna G. Mandal and Amod K. Thakur*
}

The COVID-19 pandemic is an extreme event. Lockdown in India, in a bid to slow down the pandemic, helped in reducing air pollution levels of major industrial cities (60-70\%), due to significant improvement in the air quality index. This has also contributed in reducing global carbon emissions and greenhouse gas emissions. There has been a 40-50\% improvement in the riverine water quality in terms of dissolved oxygen, biological oxygen demand, coliform bacteria levels and suspended particulate matter. These short-term environmental benefits may even pose larger threat to the environment during the post-lockdown 'as usual scenario'. Due to lockdown, agriculture and aquaculture sectors have also been severely affected. Delayed harvesting in aquaculture negatively impacted the production cost, water productivity and footprint, total water use and water use efficiency. The COVID-19 crisis has shown the vulnerability of regional to global systems in protecting our health, environment and economy. Further, this pandemic has forced us to re-examine our relationship with nature for better association. Since COVID-19 has a possibility of becoming 'just another endemic', we must learn to live with this pandemic.

Keywords: Agriculture, aquaculture, coronavirus, environmental impact, lockdown, pandemic.

THE coronavirus (CoV) disease or COVID-19 is an extreme event affecting 212 countries so far, and has become the largest pandemic since World War-II (refs 1, 2 ). The virus has been named as severe acute respiratory syndrome coronavirus-2 (SARS-CoV-2) by ICTV (International Committee on Taxonomy of Viruses). The COVID-19 virus, a single-stranded RNA virus (80$120 \mathrm{~nm})^{3}$. It is a new strain of $\mathrm{CoV}$, which has $50-80 \%$ genome sequence similarity with its old strain that had caused the Middle East respiratory syndrome (MERS) and severe acute respiratory syndrome $(\mathrm{SARS})^{4}$. The clinical spectrum for COVID-19 patients (non-specific signs to symptoms of acute respiratory infection) is similar to other $\mathrm{CoV}$ diseases. This highly transmittable virus usually spreads through close contact and respiratory droplets or aerosols that enter the human body through the respiratory system or mouth ${ }^{5}$. Infected people, both symptomatic and asymptomatic, can also spread the disease (human to human) and the morbidity rate is found to be very high in elderly/co-morbid patients ${ }^{6}$.

COVID-19 was reported first during December 2019 in Wuhan, Hubei province, Central China, and subsequently

Rajeeb K. Mohanty, Krishna G. Mandal and Amod K. Thakur are in the ICAR-Indian Institute of Water Management, Bhubaneswar 751023 , India.

*For correspondence. (e-mail: amod_wtcer@yahoo.com) spread to the rest of the world. After China, the COVID19 outbreak was severe during late February to midMarch 2020 in South Korea, Iran, Italy and other European countries, and USA. Rolling data indicate that $10,829,918$ people have been infected globally, out of which 6,048,804 have recovered and 519,417 have died as on 2 July 2020. However, despite its global spread, the intensity of COVID-19 transmission was not uniform. Generally, the number of disease outbreaks may not be directly related to climatological factors. However, tropical regions during winter ${ }^{7,8}$ and countries with absolute humidity between 4 and $9 \mathrm{~g} \mathrm{~m}^{-3}$ and temperature ranging between $4^{\circ} \pm 2^{\circ} \mathrm{C}$ and $\sim 19^{\circ} \pm 2^{\circ} \mathrm{C}$ are considered to be at a higher risk of COVID-19 outbreak.

In India, the first case of COVID-19 outbreak was testified on 30 January 2020, when an Indian student had returned from Wuhan to Kerala. No significant rise in cases was seen in February. The transmission intensified all over the country during March 2020, as several new cases were reported, mostly linked to people with a travel history to affected cities/countries. In India, the rate of infection is reported to be 1.7 , significantly less compared to the worst-affected countries. Due to the contagion of COVID-19, a nationwide lockdown was imposed in India on 25 March and later extended up to 31 July 2020 in a phased manner. The Ministry of Health and Family Welfare (MoHFW), Government of India has 
confirmed 605,323 cases of COVID-19 infection, 360,024 cases of recovery and 17,847 deaths in the country as on 2 July 2020, and more than $62 \%$ cases of infection have been reported from nine coastal states alone (Figure 1).

In general, due to low case fatality rate (CFR), pandemics are not severe public health concerns. CFR is the proportion of deaths compared to the total number of infected people with a particular disease for a certain period of time. Whereas it has caused a huge crisis and concern in political and socio-economic situations in the affected countries all over the world. Compared to other pandemics, COVID-19 is expected to cause greater human suffering in the whole world. This has also heightened wildlife conservation awareness. According to the American Veterinary Medical Association and the journal BioTechniques domestic animals and captive animals in zoos have also tested positive for COVID-19 (ref. 9). Besides affecting human lives, COVID-19 has significantly slowed down the economy not only in India, but also in the world as a whole. In this context, we analysed: (1) how the nationwide lockdown due to COVID-19 has helped nature; (2) its positive and negative impacts on the environment, agriculture and aquaculture sectors, and (3) pandemic to endemic: lessons learnt.

\section{Environmental impacts of COVID-19 crisis}

Human beings gradually started manipulating the environment from the very beginning of civilization for their own benefit. Between 1980 and 2000, more than 100

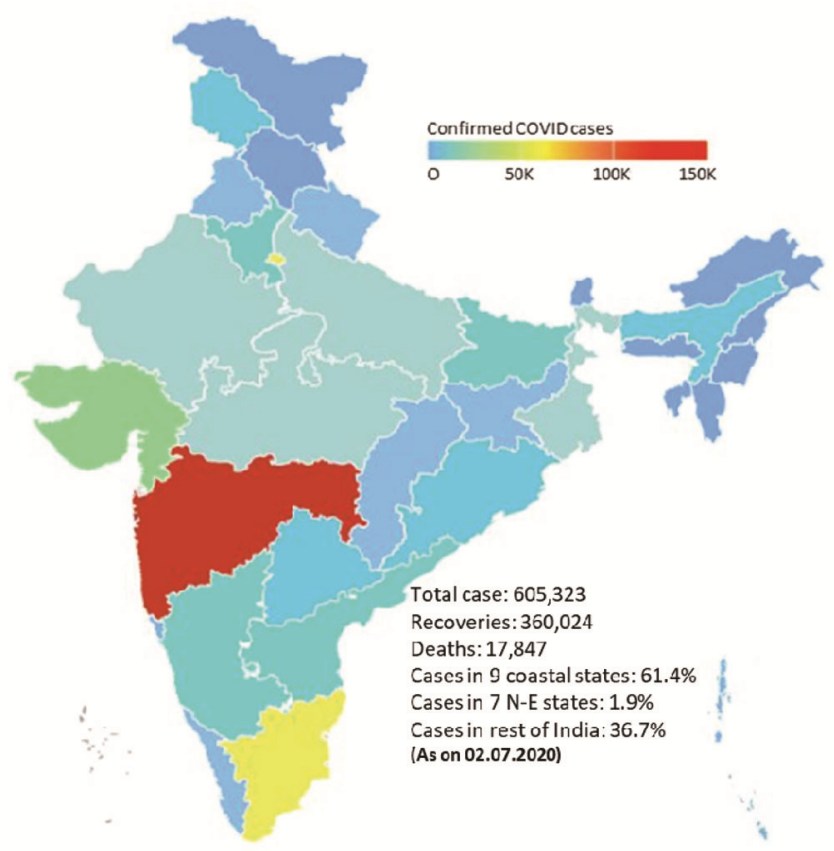

Figure 1. COVID-19 outbreak: the Indian scenario. million hectares of tropical forest and more than $85 \%$ of wetlands have been destroyed due to industrialization. During the last three decades, atmosphere, biosphere and hydrosphere have been polluted to a great extent due to the increased urbanization, industrialization and anthropogenic activities ${ }^{10,11}$. However, due to prolonged lockdown in most parts of the world ranging from weeks to months, in a bid to contain the COVID-19 spread, there was improvement in the prevailing environmental conditions.

The COVID-19 pandemic and lockdown in 2020 have subsequently disrupted the global energy use, which could reduce carbon emissions by $5 \%$ of the global total for 2019, indicating the largest ever annual fall in $\mathrm{CO}_{2}$ emissions, even more than during any previous economic crisis or war $^{9}$ (Figure 2). Due to the shutdown of industries, electricity consumption and industrial waste output have lessened to a considerable extent. There was hardly any vehicular movements on the roads, ensuing almost zero greenhouse gas (GHG) emission to the environment. Use of conventional energy sources or fossil fuels had lowered significantly mainly due to lesser demand for power in the industrial sector during the lockdown period, leading to a decline in global fossil fuel demand by $10 \%$ (ref. 12). As anticipated, in a short period, the level of carbon emissions dropped considerably ${ }^{13}$, and in China the air quality improved by $11 \%$ to the 'good' category in 337 cities $^{14}$. In China, shutting down of the industries due to COVID-19 and almost no vehicular movement on the road helped in decreasing emissions by $25 \%$ and coal use by $40 \%$ in the initial months. During February to mid-March, carbon emissions in China were down by $18 \%$ (a cut of 250 million tonnes), equivalent to $>50 \%$ of the annual output of the United Kingdom ${ }^{15}$. Similarly, a fall of around 390 million tonnes has been predicted for Europe.

Significant relationship has also been established between air pollution and COVID-19 infection through a recent study covering 120 cities in China. It infers that an increase in pollution levels $\left(10 \mu \mathrm{g} \mathrm{m}^{-3}\right)$ leads to statistically

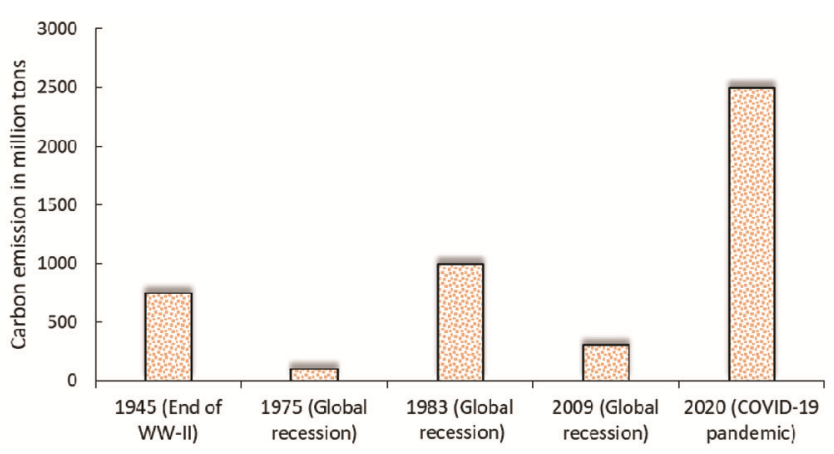

Figure 2. Biggest drop in global carbon emission due to lockdown in a bid to restrict COVID-19 spread (source: ref. 37). 
significant rise in daily counts of confirmed cases. Similarly, in USA, initial correlation between $\mathrm{PM}_{2.5}$ exposure and rate of infection indicated that higher death rates were linked to higher population density exposed to higher $\mathrm{PM}_{2.5}$ concentration. A $1 \mu \mathrm{g} \mathrm{m}^{-3}$ increase of $\mathrm{PM}_{2.5}$ in long-term average led to $8 \%$ increase in the mortality rate across USA.

In Europe (northern Italy, the UK and Spain), satellite images indicated that $\mathrm{NO}_{2}$ (nitrogen dioxide) emissions had faded away ${ }^{14}$. Satellite-based data (Sentinel-5 of ESA and Aura satellite of NASA) also confirmed a decreased level of $\mathrm{NO}_{2}$ in the atmosphere ${ }^{16}$. During FebruaryMarch 2020, the COVID-19 outbreak in major hotspots recorded a substantial fall in the level of $\mathrm{NO}_{2}$ $\left(0.00002 \mathrm{~mol} \mathrm{~m}^{-2}\right), \mathrm{CO}\left(<0.03 \mathrm{~mol} \mathrm{~m}^{-2}\right)$ and aerosol optical depth (AOD: $\sim 0.1-0.2)^{7}$. Reduction in atmospheric pollutants $\left(\mathrm{NO}_{2}\right.$ and $\left.\mathrm{AOD}\right)$ was probably due to forced shutdowns indicative of low fossil fuel consumption. Reduction in $\mathrm{PM}_{2.5}$ and $\mathrm{NO}_{2}$ levels in major hotspots when comparing the 2020 lockdown period to the same period in 2019 indicate significant improvements in air quality, except in Rome, Italy (Figures 3 and 4). Rome recorded a $30 \%$ increase in $\mathrm{PM}_{2.5}$ during the lockdown period

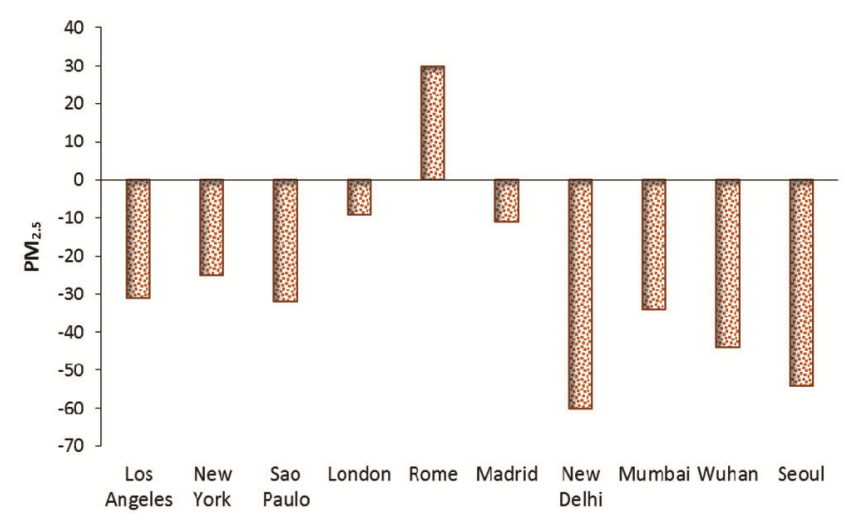

Figure 3. Reduction in $\mathrm{PM}_{2.5}$ levels when comparing the 2020 lockdown period to the same period in 2019 (source: IQ Air 2020; https://www.iqair.com/us/world-air-quality).

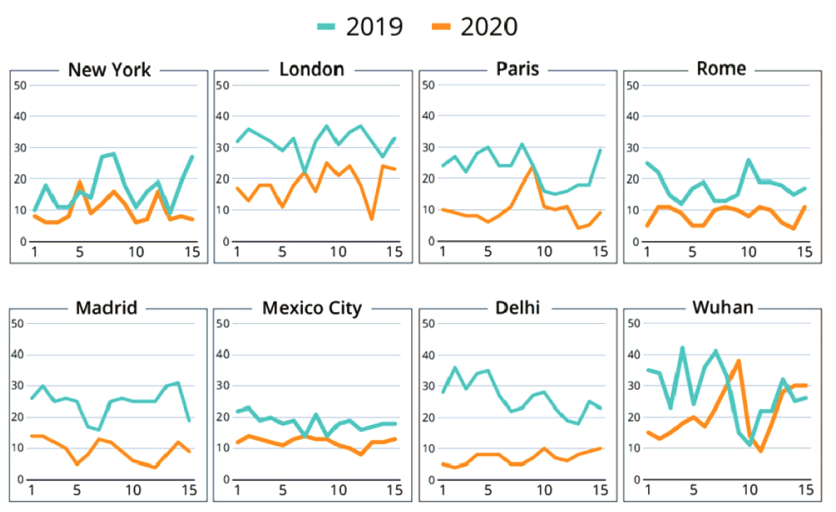

Figure 4. Daily average $\mathrm{NO}_{2}$ concentration in the air in selected cities during 1-15 April 2020 (source: ref. 38). probably due to domestic heating or increased reliance on residential heating systems, which was a significant source of air pollution in the city from November through April.

Ecosystems have also recovered well due to reduction in biochemical oxygen demand (BOD) and coliform levels in rivers, improved air quality due to decreased loading of particulate matter, nitrous oxide and other pollutants ${ }^{17}$. The extent of recovery observed in the atmosphere and hydrosphere would not have been possible without stringent measures that have been forced on the society (lockdown/shutdown) due to the COVID-19 pandemic, at the cost of trillions of dollars (US) across the world. People in most big cities are experiencing a clean and clear sky probably for the first time in their lives. On the one hand, the COVID-19 pandemic has caused worldwide devastation, while on the other hand, it has generated a positive impact on the environment. Due to the lockdown, the major sources of pollution that affect the aquatic ecosystem have shrunk or completely stopped. For example, in Italy, the Grand Canal turned clear and helped in the reappearances of most aquatic species, whereas COVID-19 crippled the whole nation ${ }^{18}$.

\section{Lockdown impacts on the Indian environment}

The COVID-19 lockdown in India has forced us to rethink on how nature is indispensable in our day-to-day lives. During lockdown, water, air and environmental systems from regional to global scales have seen visible positive impacts due to reduced pollutant loading mainly from the industries, vehicular movement and other sources. Both direct (air and water quality improvement) and indirect (climate change and land-atmosphere interactions) impacts are possible. During lockdown in India, we have seen several important environmental changes clean air to breath, greener plants/trees, spotting several wildlife inside the cities, cleaner waterbodies, rivers, sea beaches, etc. However, these environmental paybacks are temporary and the post-lockdown situation may pose larger threats to our environment.

\section{Impacts on waterbodies}

With the shutting down of industries discharging pollutants into the major river systems, water quality of the most polluted rivers in India (mainly the Ganga and the Yamuna) has improved significantly to support aquatic life. There has been a significant improvement (40-50\%) in the water quality of the Ganga (ANI report on 5 April 2020). At Varanasi, the dissolved oxygen (DO) level increased from $3.8 \mathrm{ppm}$ on 6 March 2020 to $6.8 \mathrm{ppm}$ on 4 April 2020, which enhanced the natural cleansing mechanism of the water ${ }^{19}$. According to the Uttar Pradesh Pollution Control Board, the DO levels in the upstream of 
River Ganga was $8.9 \mathrm{ppm}$ while in the downstream it was $8.3 \mathrm{ppm}$. Average BOD $(<2 \mathrm{ppm})$, total coliform count $(5000 / 100 \mathrm{ml})$ and $\mathrm{pH}(6.5-8.5)$ point to significant improvement in the riverine water quality. For the first time in decades, the Uttarakhand Pollution Control Board has recently revealed that its water had been classified as 'fit to drink after chlorination'. Due to cleaner aquatic environment in the Ganga, the critically threatened Ganges dolphins (South Asian river dolphins) have been spotted back after 30 years $^{20}$. In another study, it was reported that suspended particulate matter (SPM) concentration in Vembanad lake (India's longest freshwater lake and a Ramsar site in Kerala) declined by $15.9 \%$ compared to the pre-lockdown period ${ }^{21}$. There was also significant improvement in environmental parameters in both the hydrosphere and atmosphere.

\section{Impacts on air quality}

India's decision to put the entire country under lockdown in a bid to slow the spread of COVID-19 resulted in massive drop in air pollution levels (60-75\%), as the air quality index (AQI) of major industrial cities improved significantly compared to the previous year's data ${ }^{22}$. Eighteen out of 20 highly air-polluted cities in the world are found in India. However, a recent study indicated that maximum improvement in AQI took place in northern India, with New Delhi topping the list. The lockdowns led to significant improvement in AQI, specifically in urban areas - from worrying or poor to good. On an average, $50-60 \%$ drop in particulate matter (PM) levels was recorded over southern parts of India, while about $75 \%$ over the Indo-Gangetic basin, including Delhi, Bihar, Uttar Pradesh and West Bengal. During the lockdown period in April, AQI of New Delhi repeatedly fell below 20. If this trend continues for a year, it would surely save the lives of 6.5 lakh people, which otherwise would have been lost due to air pollution-linked health disorders ${ }^{23}$. The air quality of New Delhi usually remains above 200, which is $25 \%$ above the unsafe level as recommended by the World Health Organization (WHO). However, when 11 million vehicles in New Delhi were taken-off the roads, industries were shut down and construction works were stopped, the AQI regularly remained below 20 .

Short-term improvement in air quality contributed significantly towards reduction in global carbon emissions and suppressed GHGs, mainly due to disruption in all economic activities, traffic restrictions and changes in energy consumption pattern ${ }^{24}$. According to a recent study conducted by the Indian Institute of Technology, Delhi, India witnessed $43 \%, 31 \%, 18 \%$ and $10 \%$ fall in $\mathrm{PM}_{2.5}, \mathrm{PM}_{10}, \mathrm{NO}_{2}$ and $\mathrm{CO}$ levels during the first phase of lockdown compared to previous years. With the reduction in air pollution, people in Punjab were able to see the Himalayan ranges from more than a 100 miles away.
During phase-I of the lockdown, i.e. 25 March-15 April, about $78 \%$ people in Indian cities breathed fresh air, while most cities recorded AQI within national standards and no city was in the 'poor category' $\mathrm{AQI}^{25}$ (Figure 5). According to the Central Pollution Control Board data, $90 \%$ of the 103 Indian cities witnessed satisfactory levels of AQI during the lockdown ${ }^{26}$.

\section{Impacts on the agriculture sector}

Due to the country-wide lockdown, there has been substantial disruption in normal life and about $50-60 \%$ of all agricultural activities have come to a halt. Agriculture, aquaculture and allied sectors involve $>50 \%$ of the labour force in India. Risks are associated with food systems, and agricultural growth may experience deceleration in the medium and long term. Agriculture labourers were unable to resume work due to social distancing norms and forced into reverse migration. Nearly $85 \%$ of Indian farmers belong to small and marginal category with less than 2 ha of land and are dependent mainly on seasonal crops. The summer/rabi crops were ready for harvest in most parts of India when phase-I of the lockdown brought everything to a standstill. This was the harvesting period of plantation crops like banana, coffee and pepper. Due to COVID-19 and the lockdown, harvest of summer/rabi crops was deferred mainly because of non-availability of labour, machinery (tractors, harvesters, threshers, etc.), social-distancing norms and travel/movement restrictions. Farmers with perishable produce such as fruits, flowers and vegetables in particular incurred huge losses. Egg prices in Andhra Pradesh, Tamil Nadu, Karnataka and Odisha were at an all-time low. Small and marginal farmers involved in contract farming mainly in poultry and dairy faced huge loss, as most private sector contract firms refused to accept their produce on time.

However, the government's timely initiatives to revive the agriculture sector (ease of lockdown restriction for agriculture, financial package of INR 150,000 crores) during COVID-19, helped in continuing agriculture as

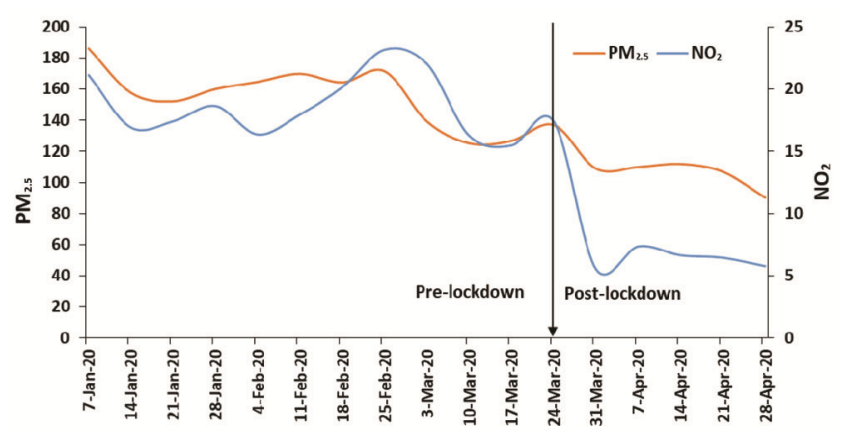

Figure 5. Average weekly nitrous oxide and $\mathrm{PM}_{2.5}$ levels in India during pre- and post-lockdown period due to COVID-19 (nationwide lockdown imposed on 25 March 2020). 
usual since the second phase of the lockdown (15 April 2020 onwards). As a result, record production of foodgrains (about 300 million tonnes) in India is expected this year with a growth of $3 \%$, despite adverse conditions ${ }^{27}$. However, this year India has enough foodgrain stock to meet any contingency. Against a requirement of 215 lakh tonnes of rice and wheat as on 1 January 2020, the Food Corporation of India has a stock of 565 lakh tonnes, roughly $2 \frac{1}{2}$ times more than that required for public distribution $^{28}$. With arrival of fresh wheat from the first half of April, India certainly need not worry about shortage of food grains. However, there is a need to strengthen self-sufficiency and self-reliance among reverse migrant workers and farmers. The challenges would be to cope with the issue of migrant workers, reduction in their incomes, protecting livelihoods of people and providing income through employment to avert destabilizing effects.

\section{Impacts on fisheries sector}

In India, fisheries sector as a whole employs over 14 million people, of which the livelihood of more than 9 million active fishers, inclusive of $80 \%$ small-scale fishers, has been affected due to COVID-19 pandemic. The Nationwide lockdown has severely affected both the capture and culture fisheries sector (Figure 6). Disruptions in transportation, migrant labour force and trade have affected the supply chain for aquaculture and aqua-food products. Due to transport restrictions, there was scarcity of shrimp seeds, feeds, liming material and related aquaculture items (e.g. aqua drugs). Restrictions and closures of global and regional markets, and the food service sector

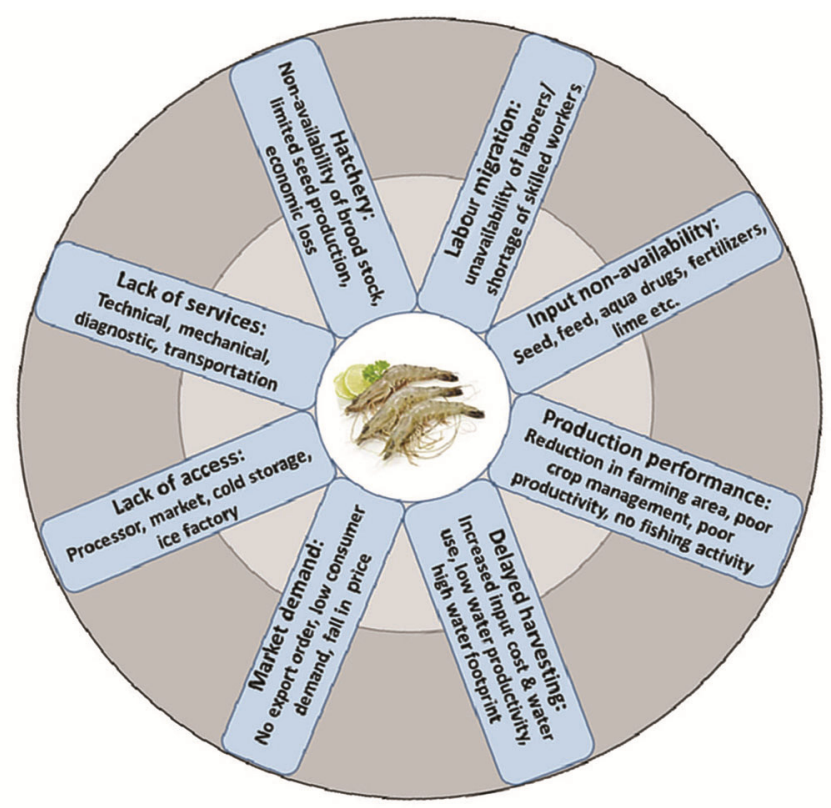

Figure 6. Challenges faced by Indian fisheries sector due to the COVID-19 lockdown. (e.g. restaurants, hotels, catering services and school/ office canteens) resulted in a drastic fall in the market, consumer demand and post-harvesting processing sector. This scenario had a substantial impact on majority of the women workforce in the post-harvest sector. Small-scale fishermen face severe risk in coastal India, where a day's catch buys that night's meal.

In the freshwater aquaculture sector, it is evident that unsold produce result in increased live fish stocks and therefore, increased costs of feeding as well as risk of mortalities. The culture duration has increased due to delayed harvesting in the lockdown period. This will increase the input cost of biomass maintenance, lower water productivity and increase water footprint ${ }^{29,30}$. Longer the duration of the culture, higher is the water exchange, evaporation and seepage losses ${ }^{31,32}$, which in turn will increase the total water use $\mathrm{e}^{33,34}$ and decrease the water use efficiency ${ }^{30}$. Low yield due to minimal/less fishing efforts in capture fisheries sector and late stocking in various aquaculture systems will lead to lower market supply of aqua-food products. This will have a knock-on effect that in turn will increase the market price and make the produce less affordable for consumers. On the other hand, small-scale aquaculture may benefit from the reduced competition with fish imports ${ }^{35}$.

According to a recent estimate ${ }^{36}$, the nationwide lockdown would result in a sharp rise in the cost of shrimp seeds by $15-30 \%$ due to reduction in hatchery seed production by $40 \%$, fall in the market price of shrimp by $30 \%$, fall in shrimp export performance by $30 \%$ and loss of employment in shrimp culture sector by $30-40 \%$ during the current season. In India, the lockdown had disrupted the major stocking season of shrimp seeds, i.e. March-April, and about $27 \%$ of farmers did not stock due to uncertainty over the culture operation and the market price. About $25 \%$ of the shrimp farms were in phase-I ( $<30$ days of culture (DOC)), 34\% in phase-II $(30-80$ DOC), and about $14 \%$ in phase-III ( $>80$ DOC). DOC itself reflects the economic impact on the farmers. Shrimp farms in early and mid-stages of rearing (phases-I and II) may not get back their investment, whereas those in phase-III could break even or make insignificant profits.

\section{Pandemic to endemic: lessons learnt}

Mike Ryan (Emergencies Director, WHO) in a recent press conference mentioned that the COVOD-19 infection may never go away and has a possibility of becoming 'just another endemic virus in our communities'. Whenever a disease is present constantly among a large number of people, it can be called an endemic (for example, malaria and chickenpox, still exist despite vaccines). So, we must learn to live with COVID-19.

This lockdown provided us a better understanding in differentiating our needs and luxuries at an individual 
level. The Sustainable Development Goals of the United Nations (UN SDGs) can only be achieved by way of balancing between the needs and luxuries at several levels, i.e. individual to community and regional to global scales. Therefore, there is a need to balance between environment, biodiversity and human health as advocated by WHO's 'One Health' initiative. Food security and zoonoses objectives of this initiative are directly related to the present COVID-19 crisis. Therefore, first and foremost is stopping the destruction of the environment. As the world will not be the same after the COVID-19 crisis, let us integrate into this 'new world' a greater respect for biodiversity. Presently, we are at a critical stage in planning how to overcome this crisis. There can be no going back to business-as-usual. Developing naturepositive stimulus packages could hold the key to averting future outbreaks, ensuring the sustainability of livelihoods. Valuing and investing in natural capital would definitely benefit rural economy, ensure sustainable supply of food and commodities, and support healthy and productive human populations.

\section{Conclusion}

It is the human hypermobility that worsened the coronavirus pandemic. This crisis has once again exposed the vulnerability of regional to global systems in protecting our health, environment and economy. COVID-19 itself is not good for any of the 17 UN SDGs. However, the pandemic is teaching us lessons in human behaviour that could bring us closer to these goals in the future. It has proved that there is no single/specific solution to an international crisis. There is an opportunity to revisit our relationship with nature for better association. Flourishing ecosystems, improved air quality and healthy riverine systems during the lockdown gave us a soothing touch, but we cannot rejoice these transitory environmental benefits. The post-lockdown business 'as usual scenario' may even pose larger threats to the environment. The lockdown helped gather baseline information for diverse environmental parameters and use this scenario towards building a sustainable development model. Zoonotic risk and response programmes are also desirable to improve the ability of a nation to lessen threats through naturefriendly approaches together with a new global mapping of risks from the unregulated habitat disintegration, wildlife trade and biodiversity loss. The COVID-19 pandemic has also made it clear that unless we act now, we run the risk of exposing ourselves to further threats in the future.

1. US Food and Drug Administration, Emergency preparedness and response to coronavirus disease 2019 (COVID-19). 2020; https:// www.fda.gov/emergency-preparedness-and-response/mcmissues/ coronavirus-disease-2019-COVID-19 (accessed on 21 May 2020).
2. Coronavirus disease (COVID-19) pandemic. World Health Organization, 2020; https://www.who.int/emergencies/diseases/novelcoronavirus-2019 (accessed on 22 May 2020).

3. Chakraborty, I. and Maity, P., COVID-19 outbreak: migration, effects on society, global environment and prevention. Sci. Total Environ., 2020; doi.org/10.1016/j.scitotenv.2020.138882.

4. Paital, B., Nurture to nature via COVID-19, a self-regenerating environmental strategy of environment in global context. Sci. Total Environ., 2020, 729; doi.org/10.1016/j.scitotenv.2020.139088

5. Riou, J. and Althaus, C. L., Pattern of early human-to-human transmission of Wuhan 2019 novel coronavirus (2019-nCoV), December 2019 to January 2020. Euro Surveill., 2020, 25(4),

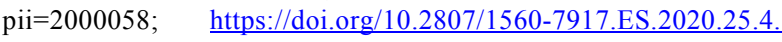
2000058.

6. Zhou, P. et al., A pneumonia outbreak associated with a new coronavirus of probable bat origin. Nature, 2020, 579(7798), 270-273.

7. Lal, P. et al., The dark cloud with a silver lining: assessing the impact of the SARS COVID-19 pandemic on the global environment. Sci. Total Environ., 2020, 732; doi.org/10.1016/j.scitotenv. 2020.139297

8. Bukhari, Q. and Jameel, Y., Will coronavirus pandemic diminish by summer? 2020; http://dx.doi.org/10.2139/ssrn.3556998 (accessed on 20 May 2020).

9. Agravante, M., COVID-19 and its effects on the environment. 2020; https://inhabitat.com/covid-19-and-its-effects-on-theenvironment/ (accessed on 23 May 2020).

10. Akimoto, H., Global air quality and pollution. Science, 2003, 302, 1716-1719.

11. Schlacher, T. A. et al., Human threats to sandy beaches: a metaanalysis of ghost crabs illustrates global anthropogenic impacts. Estuarine Coastal Shelf Sci., 2016, 169, 56-73.

12. SCRIPPS, Research in the time of COVID-19. 2020; https:// scripps.ucsd.edu/news/research-time-covid-19 (accessed on 17 April 2020).

13. Stone, M., Carbon emissions are falling sharply due to coronavirus. But not for long. 2020; https://www.nationalgeographic. com/science/2020/04/coronavirus-causing-carbon-emissions-to-fallbut-not-for-long/ (accessed on 17 April 2020).

14. Henriques, M., Will Covid-19 have a lasting impact on the environment? BBC News, 2020; https://www.bbc.com/future/article/ 20200326-covid-19-the-impact-of-coronavirus-on-the-environment (accessed on 23 April 2020).

15. Watts, J., Climate crisis: in coronavirus lockdown, nature bounces back - but for how long? 2020; https://www.theguardian.com/ world/2020/apr/09/climate-crisis-amid-coronavirus-lockdown-naturebounces-back-but-for-how-long (accessed on 23 May 2020).

16. ESA, COVID-19: nitrogen dioxide over China. 2020; https:// www.esa.int/Applications/Observing the Earth/Copernicus/Sentinel5P/COVID-19 nitrogen dioxide_over_China (accessed on 17 April 2020).

17. Ritchie, H. and Roser, M., Water use and stress. 2020; https:// ourworldindata.org/water-use-stress (accessed on 23 May 2020).

18. Clifford, C., The water in Venice, Italy's canal is running clear amid the COVID-19 lockdown - take a look. 2020; https:// www.cnbc.com/2020/03/18/photos-water-in-venice-italys-canalsclear-amid-covid-19-lockdown.html (accessed on 17 April 2020).

19. Meheta, K., Ganga River before and after lockdown: 5 facts you should know. 2020; https://www.timesnownews.com/mirror-now/ in-focus/article/ganga-river-before-and-after-lockdown-5-facts-youshould-know/584305 (accessed on 17 May 2020).

20. Goswami, K., Covid-19: 4 unbelievable environmental changes seen in India since lockdown. 2020; https://www.indiatoday.in/ education-today/gk-current-affairs/story/covid-19-4-vital-environmental-changes-evidenced-in-india-since-lockdown-1673726-202005-02 (accessed on 17 May 2020).

21. Yunus, A. P., Masago, Y. and Hijioka, Y., COVID-19 and surface water quality: improved lake water quality during the lockdown. 
Sci. Total Environ., 2020, 731; doi.org/10.1016/j.scitotenv.2020. 139012.

22. Koundal, A., COVID-19 lockdown: air quality in India's major industrial cities improve by up to $60 \%$ compared to last year. 2020; https://energy.economictimes.indiatimes.com/news/oil-and-gas/ covid-19-lockdown-air-quality-in-indias-major-industrial-citiesimprove-by-up-to-60-compared-to-last-yr/74931010 (accessed on 18 May 2020).

23. Wallen, J., India's cleaner lockdown air could save 650,000 lives. 2020; https://www.telegraph.co.uk/global-health/science-and-disease/ indias-cleaner-lockdown-air-could-save-650000-lives/ (accessed on 19 May 2020).

24. Wang, Q. and Su, M., A preliminary assessment of the impact of COVID-19 on environment - a case study of China. Sci. Total Environ., 2020, 728; doi.org/10.1016/j.scitotenv.2020.138915

25. Sharma, R., 78 per cent Indian cities breathed clean air during phase one of COVID-19 lockdown. 2020; https://www. newindianexpress.com/nation/2020/apr/23/78-per-cent-indian-citiesbreathed-clean-air-during-phase-one-of-covid-19-lockdown-2134080.html (accessed on 19 May 2020).

26. Prasad, P., Lockdown unlocks fresh air, Bengaluru breathes easy. 2020; https://www.newindianexpress.com/cities/bengaluru/2020/may/ 02/lockdown-unlocks-fresh-air-bengaluru-breathes-easy-2138128. html (accessed on 19 May 2020).

27. Dutta, P. K., Indian economy in corona time: agriculture only bright spot. 2020; https://www.indiatoday.in/news-analysis/story/ coronavirus-lockdown-covid-19-impact-on-economy-agriculture1674545-2020-05-05 (accessed on 23 May 2020).

28. Gunjan, R. K., Plummeting sale of agricultural produce may hit India's ability to feed after coronavirus pandemic. 2020; https:// www.news $18 . c o m / n e w s /$ india/diminished-agricultural-selling-maynow-impact-indias-ability-to-feed-after-coronavirus-pandemic-2596237.html (accessed on 23 May 2020).

29. Mohanty, R. K., Mishra, A., Panda, D. K. and Patil, D. U., Water budgeting in a carp-prawn polyculture system: impacts on production performance, water productivity and sediment stack. Aquac. Res., 2016, 47, 2050-2060.
30. Mohanty, R. K., Ambast, S. K., Panigrahi, P., Thakur, A. K. and Mandal, K. G., Enhancing water use efficiency in monoculture of Litopenaeus vannamei: impacts on pond water quality, waste production, water footprint and production performance. Aquacult. Eng., 2018, 82, 46-55.

31. Mohanty, R. K., Ambast, S. K., Panda, D. K., Thakur, A. K. and Mohanty, S., Density-dependent water use in carp polyculture: impacts on production performance and water productivity. Aquaculture, 2017, 470, 32-39.

32. Boyd, C. E., Water use in aquaculture. World Aquacult., 2005, 36(3), 12-15; 70.

33. Mohanty, R. K., Mishra, A., Ambast, S. K., Mandal, K. G., Panda, D. K. and Panigrahi, P., Effects of various shrimp (Penaeus monodon) densities on their growth, water and sediment quality, and water budget. Aquacult. Int., 2017, 25, 2161-2176.

34. Boyd, C. E. and Gross, A., Water use and conservation for inland aquaculture ponds. Fish. Manage. Ecol., 2000, 7(1-2), 55-63.

35. FAO, How is COVID-19 affecting the fisheries and aquaculture food systems. Food and Agriculture Organization, Rome, 2020; https://doi.org/10.4060/ca8637en (accessed on 19 May 2020).

36. CIBA, Impact of corona virus disease (COVID-19) related lockdown on shrimp aquaculture sector in India: issues and way forward. ICAR-Central Institute of Brackishwater Aquaculture, Chennai, 2020; http://www.ciba.res.in/wp-content/uploads/2020/ 05/ICAR-CIBA_Impact_COVID-19way-forward.pdf (accessed on 19 May 2020)

37. Roper, W., COVID-19 could cause historic drop in carbon emissions, 2020; https://www.statista.com/chart/21414/record-drop-incarbon-emissions/ (accessed on 20 May 2020).

38. WAQI, World Air Quality Index, 2020; https://waqi.info/ (accessed on 20 May 2020).

Received 12 June 2020; revised accepted 7 July 2020

doi: $10.18520 / \mathrm{cs} / \mathrm{v} 119 / \mathrm{i} 8 / 1260-1266$ 